\title{
STRATEGY OF PROTECTION OF FINANCIAL SECURITY OF JOINT STOCK COMPANIES
}

In the article features of strategy of protection of financial safety of joint-stock companies are considered. The author examines the features and corresponding gaps that need to be improved in legislation on the effectiveness of financial protection of shareholders' rights, as this is quite an important argument for reproducing innovations in Ukrainian legislation. As a consequence, conclusions were formulated on the improvement of the legal system for the protection of financial and legal security. The need to systematize the strategy of legal planning of the system of ensuring the financial safety of joint-stock companies is updated.

Key words: joint-stock company, financial security, legal protection of shareholder rights, strategic plan.

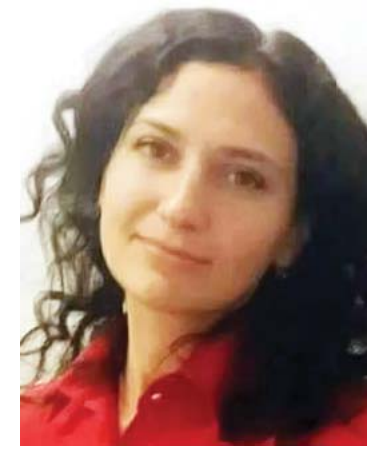

Oksana Nazarchuk, Post-graduate Student of the EducationalScientific Institute "The Juridical Institute of SHEI "Vadym Hetman Kyiv National Economic University" lawnazarchuk@ukr.net

\section{Introduction}

In conditions of growing openness and consistent international integration, ensuring financial security is an urgent task. This is due to the influence of the external environment, which today is characterized by the elements of deepening the financial crisis and internal environment, in particular, by increased competition and business consolidation. The authority of the above-mentioned act causes the emergence of threats that prevent the process of implementing strategic directions for the development of joint-stock companies in terms of profitability and risk minimization.

The vector state of the organizational and legal framework of Ukraine, in which the financial and economic activities of joint-stock companies are applied (hereinafter referred to as the JSC), is to a certain extent an open and efficient market system where the entire range of legislative decisions accumulated by developed foreign states is used.

The strategy of global factors for the financial security of domestic JSC is observed through the activities of transnational banks and corporations, the creation of new investment opportunities, and in turn, the existence of potential threats. The materials and methods of these reflections make it possible to see that the implementation of the defense system is not reliable enough, and in some cases, unpredictable or unexpected.

The problems of ensuring financial security of JSC were investigated by such domestic scientists, in par- 
ticular: N.M. Davidenko, V.I. Franchuk, I.P. Shulga. A significant contribution to the development of theoretical aspects of financial security of individual business entities was also carried out by such scientists as A.I. Baranovskii, S.S. Varnaliy, V.M. Geets, A.V. Gukova, N.V Duleba, A.A. Epifanov, M.M Ermoshenko, S.A. Koblya, V.I. Kutzik, R.S. Papekhin, A.I. Sukhorukov, V.T. Shlemko and others.

The purpose of the article is to analyze features and identify the corresponding gaps that need to be improved and/or corrected, as the effectiveness of protection of management and ensuring shareholders' rights becomes an important argument for the reproduction of innovations in the legislation of Ukraine. That is why JSC will have an opportunity to attract resources if those who provide them will be sure that their rights are surely guaranteed, and in case of violation, their maximum legal protection is possible.

\section{The legal etymology of the financial security strategy}

The legal sequence of actions aimed at achieving certain long-term goals and solving current tasks in joint-stock companies that arise in the process of obtaining them under the influence of the external environment, using the existing opportunities, reveals the very concept and meaning of the word "legal strategy".

That is, the strategy, as a result of managerial activity, must correspond to the signs of planning, an informed target direction, orientation to a long-term perspective. Of course, the planned legal nature of the strategy system is justified in the dialectical combination of the organization, as an element of the strategic process and as a result of the design process.

First of all, an understanding of legal strategy provides for the scope of efforts to achieve the goal. Usually, the competitive strategy of the JSC is aimed at implementing significant changes and/or its competitive position in the legal aspect.

Investigating the evolutionary aspect of the essence of the concept of "financial security of the JSC" is a multifaceted aspect of the formation of security features and preservation in the current conditions of development of the Ukrainian economy in general and the financial system in particular.

So, as you know, financial security is one of the most important components of the elements. Legal financial security is an indispensable attribute of achieving not only sustainable financial and economic development of enterprises, but also ensuring the sustainable development of the national economy. Providing reliable legal protection of material and financial resources, creating a legislative and regulatory basis for the operation of the JSC, the state ensures the growth of the legal level of financial security of the national economy in general and the financial system in particular. This increases the legal financial capacity of the state and forms legal preconditions for the sustainable development of society through cultural, defense, information, educational, medical and other components.

Thus, the legal financial security of the joint-stock company is a whole complex and affects practically all the functional areas of the JSC's activities, and when assessing the legal financial security, a number of provisions of the evaluation overlap with certain activities of the JSC, this concerns, first of all, the formulation of the strategic interests of the society itself and their quantitative interpretation.

3. Mechanism of protection of financial security of JSC

Providing financial security for JSC is one of the main and priority tasks, leading to all structural units and all employees of the JSC, and next to the task of increasing profits 
and improving the well-being of shareholders. Effective protection is provided only in case of the combined efforts of management, the work collective and the shareholders themselves.

Headliner for today (from English headline - "the author of headings", the hero of headlines, the high spot "the leading executor"), for example, it is possible to result increase in requirements to business transparency, where the keynote is the requirement to PJSC (Public Joint Stock Company) to create the most transparent and, which is no less important, a balanced system of decision-making within the company and to disclose almost all the essential information about the company to its stakeholders (the Law of Ukraine "On Amending Certain Legislative Acts of Ukraine on simplifying the conduct of business and holding investment by securities issuers", 2017). The law solves the problem of distribution of joint-stock companies in Ukraine to public and private ones on formal grounds, eliminates imbalances in legislation and introduces European principles in the definition and regulation of public companies.

According to the representatives of the National Securities and Stock Market Commission, absolute transparency of public companies is a payment of such companies for the possibility of attracting cheap financial resources, where PJSC can get through entering the capital market (Public and private joint-stock companies, 2018).

However, the definition of financial security of JSC is associated with certain difficulties.

First, the available studies of the theoretical and legal aspects of financial security are not unambiguous and differ in their results.

Secondly, the theoretical approaches to the content filling of the financial security category of business entities are not always considered and suggested by researchers and practitioners, they can not always take into account such features of their functioning as: the form of ownership, the organizational and legal form, the scale of the enterprise's activities, and the like.

Thirdly, an extremely complex aspect is the ability of JSCs to quickly adapt to new business conditions, caused by the impact of threats, and to maintain the necessary level of their financial security.

Consequently, the above-mentioned aspects call for further research into the development of the financial safety category of the JSC.

Application of legal financial security JSC is one of the necessary conditions for its stable and efficient financial and economic activities, to ensure that the company achieves its strategic goals. At the same time, negative changes in the state of the economy as a whole do not provide societies with sustainable economic growth and their expanded reproduction. The presence in the JSC of opportunities to resist and minimize the negative impact of factors on the performance of enterprises, is reflected in the formation of a legal system for their financial security.

Legal financial security of each business entity faces certain threats. Threats, as a rule, are understood as causes and conditions that create a danger to the interests of the enterprise.

It is important to know that the accuracy of each legal assessment model depends on the reliability of the information on which the model is built. Each valuation cost is 
unique. Some types of information become more or less important, depending on the growth phase of the JSC, the industry to which it belongs, and the overall perspective.

For example, in general, both analysts and fund managers in the UAE use accounting information with reference to its reliability and significance, and they greatly reduce information that matters but whose payback is uncertain (for example, research and development). The quality of management and the sustainability of efficiency are highly valued by both analysts and fund managers in the UAE. This is due to the fact that management has the ability to influence future performance, and this ability can be noted and also evaluated (D'Amato, Gallo, 2017).

As for the Kazakhstani innovation, this has become an urgent problem for the last 20 years. Therefore, the country is a far-sighted way of developing innovation infrastructure and its promotion among various companies. A general study showed that companies perceive innovation as modernization and reconstruction. For example, in the report of JSC "NSC" Kazatomprom it was noted: "Within the framework of the financial incentive system there exists a policy of rewarding employees with innovative ideas, exemplary performance of important tasks, continuous and impeccable work and other merits - implemented" (Mukhtarova, Yesbolganova, 2018).

In the conditions of the budget deficit and the reform of the public administration system in accordance with the requirements of the legislation, the study of national projects based on foreign experience acquires particular urgency. So, in Ukraine there was a catalog of Ukrainian investors in startups, where the association UVCA (Ukrainian Association of Venture Capital and Private Capital) collected data on active investors of Ukraine in a single catalog of Investors Book, thanks to which there is information about venture funds, accelerators and incubators, private equity funds and other participants of the investment market. The catalog allows you to find out the names of the funds with their contact details, find portfolio companies, criteria for selecting start-ups, the investment strategy in full, the average volume of the round (The most active Ukrainian investors in startups, 2017).

The financial safety of the JSC should include a set of methods, levers and tools to ensure the state of the most effective use of financial resources of the JSC, that allows identifying and leveling the negative impact of external and internal factors affecting the business entity to maximize welfare, protect and maintain a balance of financial interests of founders, small shareholders and managers of corporate structures (Bilous, 2017).

First of all, the legal strategy - takes into account changes in the external environment, which can affect the level of achievement of the set goals and provide an early and adequate response when using all available resources. It combines deliberate and purposeful actions and legal measures taken in case of unforeseen developments in the JSC. New forms of financial and legal relations arising between subjects and objects of financial security of joint-stock companies, should be evaluated for their safety.

Undoubtedly, a significant step was taken with the adoption of the Law of Ukraine "On Amendments to Certain Legislative Acts of Ukraine Concerning Enhancing the Level of Corporate Governance in Joint-Stock Companies". The law introduced an institution such as squeeze-out and sell-out. Sell-out will allow minority shareholders to demand from the shareholder - the owner of $95 \%$ of the company's shares to acquire 
at a fair price the shares that belong to them. With the help of this mechanism, minority shareholders will be able to avoid losses from owning small packages of securities (On amendments to certain legislative acts of Ukraine on increasing the level of corporate governance in joint-stock companies. Law of Ukraine, 2017).

Effective counteraction to threats to the economic security of the state is possible only if the system of timely detection and elimination of systemic threats in public finance is established and prevented in the future. It was with this goal in mind that the bill "On the National Bureau of Financial Security of Ukraine" was registered in the parliament (Draft Law on the National Bureau of Financial Security of Ukraine, 2018).

The task of the bill is to create a single law enforcement agency, to which the crimes in the field of public finances will belong, and which will carry out its activities on a conceptually new basis - the ILP (Intelligence Led Policing) model - an organization of law enforcement activity, managed by analysts.

Ukraine, having signed the Association Agreement with the European Union, has undertaken to bring its legislation in line with EU standards, as well as to take measures to improve the investment climate.

It will be really interesting in the system of financial protection of AT, buying and selling Ukrainian shares. In any case, it will be possible to buy securities on Western European exchanges, although taxes will have to be paid in Ukraine from the income received from securities transactions in the EU countries. It is suggested that the association will make it possible to simplify the flow of capital from Ukraine to the EU and back. This should stimulate the flow of real foreign investment from the EU countries (Concerning the Temporary Application of an International Contract, 2015).

\section{Conclusions}

Protecting the rights of shareholders is the main and necessary condition for attracting capital. Now, the JSC are in the stage of updating production and entering new markets. Acceleration and complications of changes in the business environment is a characteristic feature of most modern markets.

Each strategy, which has passed to the implementation stage, requires constant adjustments and clarifications of the direction of the enterprise, ways to acquire and realize competitive advantages, the intensity and volume of strategic changes, and the like. It is clear that the form of such a strategy can not remain unchanged. This is a permanent process that can be completed only if a decision is made about the inexpediency of further development within the framework of the current strategy.

Analyzing the problematic aspects of the financial and legal security of the JSC, one should agree with the approaches that such threats are: unfavorable macroeconomic conditions: government crises; instability of the regulatory framework; tax, credit and insurance policies; inflation rate and inflation forecast; instability of the monetary policy of the state; lack of funds for investing in the region, low level of investment activity; adverse credit conditions for enterprises, changes in interest rates on loans; unfair competition in the market; the spread of criminal and financial crimes in the financial and credit sphere.

At the same time, this logic leads to the conclusion that the presence of threats can not always be interpreted as a negative moment for JSC's financial security, but on the 
contrary, the presence of certain threats can be an incentive for increasing the efficiency of financial and economic activity, while at the same time it will ensure growth level of financial security of corporate structures. At the heart of the synergetic effect in the process of ensuring the financial security of the JSC will be various factors that can contribute to maximizing (minimizing) the market value of the JSC as the ultimate goal of ensuring their financial and legal security.

Conceptually, the formation of an effective system for protecting the financial security of joint-stock companies should be based on the creation of integrated monitoring, that is, a multi-level and full-scale system for monitoring the dynamics of all major economic and legal processes in the country. The obvious difficulty is the development of precise criteria and levels of financial security.

Implementation of the legal strategy for protecting the financial security of jointstock companies is impossible without the use of tactics and operational actions, whereas without a pre-selected strategy, tactics and operational actions can not ensure the stable operation of the object of management in the future. The existence of tactics, operational actions and strategy allows us to distinguish tactical, operational and strategic management. Therefore, the application of the planned strategy will give impetus to the new level of development of the JSC, will affect the financial and legal climate in Ukraine.

\section{Bibliography:}

1. Про внесення змін до деяких законодавчих актів України щодо спрощення ведення бізнесу та залучення інвестицій емітентами цінних паперів: Закон України від 16 листопада 2017 р. № 2210-VIII / Верховна Рада України. URL: http://zakon0.rada.gov.ua/laws/ show/2210-19 (дата звернення: 01.07.2018).

2. Проект Закону про Національне бюро фінансової безпеки України від 19 березня 2018 p. № 8157. / Верховна Рада України. URL: http://w1.c1.rada.gov.ua/pls/zweb2/webproc4_2?id= \&pf3516=8157\&skl=9 (дата звернення: 02.07.2018).

3. Про внесення змін до деяких законодавчих актів України щодо підвищення рівня корпоративного управління в акціонерних товариствах: Закон України від 23 березня 2017 р. № 1983-VIII / Верховна Рада України. URL: http://zakon5.rada.gov.ua/laws/show/1983-19 (дата звернення: 02.07.2018).

4. Білоус В.Т. Правове регулювання інвестиційної безпеки - складова фінансової безпеки держави. Наука і правоохорона. 2017. № 1(35). С. 12-20.

5. Голозубова Ю.В. Теоретичні підходи до визначення поняття «механізм управління фінансовою безпекою». URL: http://repository.hney.edu..ua/jspui/bitstriam/123456789/1400/1 (дата звернення: 02.07.2018).

6. Щодо тимчасового застосування міжнародного договору: лист Міністерства закордонних справ України від 30 листопада 2015 р. № 72/14-612/1-2980 / Міністерство закордонних справ України. URL: http://zakon2.rada.gov.ua/rada/show/v2980321-15 (дата звернення: 05.07.2018).

7. Найактивніші українські інвестори в стартапи. URL: http://items.ua/ua/publication/ Samye-aktivnye-ukrainskie-investors-v-startapy (дата звернення: 02.07.2018).

8. Публічні та приватні акціонерні товариства: про зміщення меж. URL: http://us.ligazakon.ua/ua/magazine_article/EA011255 (дата звернення: 04.07. 2018).

9. Стратегія підприємства: зміна парадигми управління та інноваційні рішення для бізнесу / за ред. А.П. Наливайка. К.: КНЕУ, 2015. 398 с. 
10. Акімова Н.С., Говоруха О.О., Топоркова О.В., Євлаш Т.О. Обліково-аналітичні аспекти основних операцій акціонерного товариства: теорія і практика: монографія. Х.: ФОП Бровін О.В., 2016. 306 с.

11. Global Corporate IT Security Risks: 2016. URL: http://novosti-it.pp.ua/bezopasnost/1286.

12. Ireland P. Efficiency or Power? The Rise of the Shareholder-oriented Joint Stock Corporation. Indiana Journal of Global Legal Studies. 2018. Vol. 25. № 1. P. 291-330. URL: https://www.jstor.org/stable/10.2979/indjglolegstu.25.1.0291.

13. Mukhtarova K., Yesbolganova G. Perception of innovations by public enterprises in Kazakhstan. Academy of Strategic Management Journal. 2018. Vol. 17. Iss. 1. URL: https://www.abacademies.org/articles/Perception-of-innovations-by-public-193-6104-17-1-166.pdf.

14. D’Amato A., Gallo A. Does Bank Institutional Setting Affect Board Effectiveness? Evidence from Cooperative and Joint-Stock Banks. URL: https://doi.org/10.1111/corg.12185.

\section{References:}

1. Verkhovna Rada of Ukraine (2017). Pro vnesennia zmin do deiakykh zakonodavchykh aktiv Ukrainy shchodo sproshchennia vedennia biznesu ta zaluchennia investytsii emitentamy tsinnykh paperiv: Zakon Ukrainy [On Amendments to Certain Legislative Acts of Ukraine on Facilitation of Business and Investment Attraction by Securities Issuers: Law of Ukraine]. Retrieved from: http://zakon0.rada.gov.ua/laws/show/2210-19.

2. Verkhovna Rada of Ukraine (2018). Proekt Zakonu pro Natsionalne biuro finansovoi bezpeky Ukrainy [Draft Law on the National Bureau of Financial Security of Ukraine]. Retrieved from: http://w1.c1.rada.gov.ua/pls/zweb2/webproc4_2?id=\&pf3516=8157\&skl=9.

3. Verkhovna Rada of Ukraine (2017). Pro vnesennia zmin do deiakykh zakonodavchykh aktiv Ukrainy shchodo pidvyshchennia rivnia korporatyvnoho upravlinnia $\mathrm{v}$ aktsionernykh tovarystvakh: Zakon Ukrainy [On Amendments to Certain Legislative Acts of Ukraine on Increasing the Level of Corporate Governance in Joint-Stock Companies: The Law of Ukraine]. Retrieved from: http://zakon5.rada.gov.ua/laws/show/1983-19.

4. Bilous, V.T. (2017). Pravove rehuliuvannia investytsiinoi bezpeky - skladova finansovoi bezpeky derzhavy [Legal regulation of investment security - a component of financial security of the state]. Nauka i pravookhorona, no. 1(35), pp. 12-20.

5. Holozubova, Yu.V. Teoretychni pidkhody do vyznachennia poniattia "mekhanizm upravlinnia finansovoiu bezpekoiu" [Theoretical approaches to the definition of "financial security management mechanism"]. Retrieved from: http://repository.hney.edu..ua/jspui/ bitstriam/123456789/1400/1.

6. Ministry of Foreign Affairs of Ukraine (2015). Shchodo tymchasovoho zastosuvannia mizhnarodnoho dohovoru: lyst [Concerning the Temporary Application of an International Contract: Letter]. Retrieved from: http://zakon2.rada.gov.ua/rada/show/v2980321-15.

7. Naiaktyvnishi ukrainski investory $\mathrm{v}$ startapy [The most active Ukrainian investors in startups]. Retrieved from: http://items.ua/ua/publication/Samye-aktivnye-ukrainskie-investors-vstartapy.

8. Publichni ta pryvatni aktsionerni tovarystva: pro zmishchennia mezh [Public and private joint-stock companies: on the offset of borders]. Retrieved from: http://us.ligazakon.ua/ua/ magazine_article/EA011255.

9. Nalyvaiko, A.P. (ed.) (2015). Stratehiia pidpryiemstva: zmina paradyhmy upravlinnia ta innovatsiini rishennia dlia biznesu [Enterprise strategy: changing management paradigm and innovative business solutions]. Kyiv: KNEU. [in Ukrainian].

10. Akimova, N.S., Hovorukha, O.O., Toporkova, O.V., Yevlash, T.O. (2016). Oblikovoanalitychni aspekty osnovnykh operatsii aktsionernoho tovarystva: teoriia i praktyka: monohrafiia 
[Accounting and analytical aspects of the basic operations of the joint-stock company: theory and practice: a monograph]. Kharkiv: FOP Brovin O.V. [in Ukrainian].

11. Global Corporate IT Security Risks: 2016. Retrieved from: http://novosti-it.pp.ua/ bezopasnost/1286.

12. Ireland, P. (2018). Efficiency or Power? The Rise of the Shareholder-oriented Joint Stock Corporation. Indiana Journal of Global Legal Studies, Vol. 25, no. 1, pp. 291-330. Retrieved from: https://www.jstor.org/stable/10.2979/indjglolegstu.25.1.0291.

13. Mukhtarova, K., Yesbolganova, G. (2018). Perception of innovations by public enterprises in Kazakhstan. Academy of Strategic Management Journal, Vol. 17, Iss. 1. Retrieved from: https://www.abacademies.org/articles/Perception-of-innovations-by-public-193-6104-17-1-166.pdf.

14. D'Amato, A., Gallo, A. Does Bank Institutional Setting Affect Board Effectiveness? Evidence from Cooperative and Joint-Stock Banks. Retrieved from: https://doi.org/10.1111/ corg. 12185.

\title{
СТРАТЕГІЯ ЗАХИСТУ ФІНАНСОВОЇ БЕЗПЕКИ АКЦІОНЕРНИХ ТОВАРИСТВ
}

\author{
Назарчук Оксана Михайлівна, \\ аспірант \\ Навчально-наукового інституту «Юридичний інститут \\ ДВНЗ «Київський національний економічний університет імені Вадима Гетьмана» \\ lawnazarchuk@ukr.net
}

У статті розглянуто особливості стратегії захисту фінансової безпеки акціонерних товариств. Автор досліджує особливості та відповідні прогалини, які потребують вдосконалення законодавства щзодо ефективного фінансового захисту прав акиіонерів, адже ие є досить важливим аргументом для відтворення нововведень законодавства Украйни. Як наслідок, сформульовано висновки щцодо вдосконалення правової системи захисту фінансово-правової безпеки. Актуалізовано потребу у систематизації стратегї правового планування системи забезпечення фінансової безпеки акціонерних товариств.

Ключові слова: акціонерне товариство, фінансова безпека, правовий захист прав акціонерів, стратегічний план. 